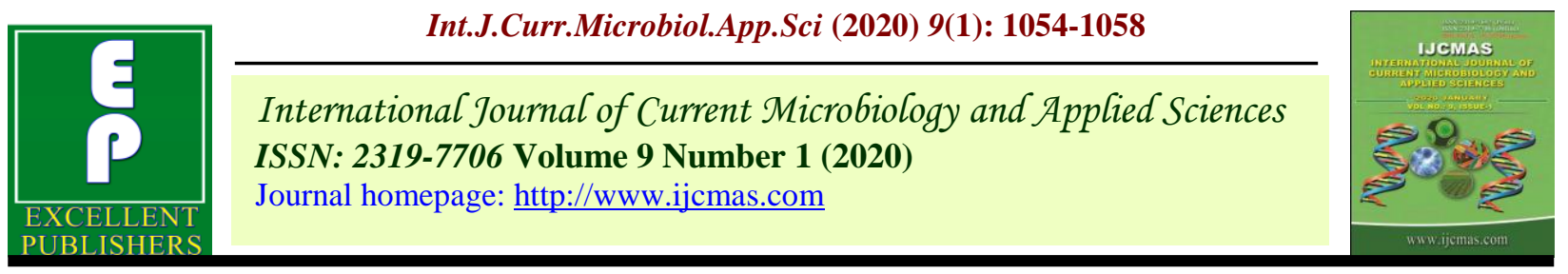

Original Research Article

https://doi.org/10.20546/ijcmas.2020.901.118

\title{
A Study on Fish Marketing System in Himmatnagar, Sabarkantha, Gujarat
}

\author{
S. R. Vala*, S. R. Lende, K. Jora, H. Dhimmar, J. Mevada, D. Fofandi and S. Dhimmar \\ Post Graduate Institute of Fisheries Education and Research, \\ Kamdhenu University, Gandhinagar-382010, India \\ *Corresponding author
}

\section{A B S T R A C T}

\section{Keywords}

Fish marketing system,

Himmatnagar, Carp,

Exotic carp, Cat

fishes, Hilsa,

Pomfret and

shrimps

Article Info

Accepted:

15 December 2019

Available Online:

20 January 2020
The study was conducted at fish markets in Himmatnagar, Sabarkantaha, and attempts study present marketing system, marketing activity and economic features. This paper to identify market facilities, present market status, nature of cost and the factor influence the market system. In Himmatnagar nearly all fish traded within move through the privet sector, a large number of people are give and take fish distribution and marketing system. The main source of fishes in Himmatnagar fish market is Dharoi dam, lake, small rivers and reservoir which supply various verities of fishes. Virtually most of fish near about $30 \%$ is locally supplied, near about $70 \%$ of fish are transfer to Ahemdabad. The freshwater fishes and marine fish are available near about $80 \%$ and $20 \%$ respectively. Major available fish's species in Himmatnagar market are Indian major carp, exotic carp, cat fishes, hilsa, pomfret and shrimps.

\section{Introduction}

The fisheries sector has been recognized as a powerful income generator as it stimulates growth of a number of subsidiary industries and is a source of cheap and nutritious food. (Chourey et al., 2013) fisheries is an important sector in India contributing about $5.15 \%$ of agriculture GDP of country and fisheries sector contribution around $1.1 \%$ of total GDP. India contributes about $6.3 \%$ of global fish production fish is an important source of protein and important food for daily diet. Marketing is involved from the point of production and the consumers. Fish available to consumers at right time and place to required an effective marketing system. The growth of fish production as well as development of fishery sector in terms of economy and infrastructure is highly dependent on an efficient fish marketing system (Chourey et al., 2014).

In India most of the fish production and capture sold in local markets. Most of the markets are still in development stage and only few having facilities. Major hindrance in 
fish marketing includes perish ability and large quantities, storage, transportation, quality and quantity of commodity, low demand elasticity and high price spread (Ravindranath et al., 2008).

Himmatnagar Town is standing at about 80 far from Ahmadabad on banks of Hathmati River a tributary of Sabarmati River. Himmatnagar is having substantial recourses such as river, lakes, village lakes, reservoirs etc. The main source of fishes in Himmatnagar fish market is Dharoi dam. It only resources that produced substantial amount of fish catch while are most sold in local and domestic market. The fishermen utilized local resources and gather their catches in to the market place. The present study was carried out to analyze the market with market facilities, cold chain, hygiene, major species sold, price structure, market building, women involvement and marketing system.

\section{Materials and Methods}

The present study was carried out to analyses the condition of market, market facilities, cold chain, market building, major species sold, price structure. The present study is based on primary sources of data. The primary data are collected by the survey of fish market with help of direct observation, interview technique, and questionnaire. The data collected through field visit, interview individual, and observation in market at Himmatnagar.

\section{Study area}

Fish market located at Himmatnagar town and Sabarkantha district were area of study in the present work. It is one of the common and well known fish markets in Himmatnagar. The data was collected over the three day from $18^{\text {th }}$ November to $20^{\text {th }}$ November 2019.

\section{Observation}

It was found that, bigger size fishes are comparatively higher amount than the smaller fishes. The price fluctuation in fishes is very high because of the uncertain of catch production and sort run supply. After the closing time of market, the fishermen stored unsold fishes in refrigerator otherwise sell their fishes at low rates. Following table shows day wise list of market, Himmatnagar town.

During the study period following chart indicating the path of movement of fish from the producers to the consumers:-

\section{Fishermen - Auctioneers - Retailers - Consumers.}

2. Fishermen - Auctioneers - Consumers.

\section{Results and Discussion}

The present study was carried out to analyze the current situation of different areas fish market. The studied with market building, market facilities, cold chain, hygiene, major sold species, price structure, women involvement and marketing system. The present study outcome elaborates below.

\section{Market building}

Mehtapura market 1 and Mehtapura market 2 has special building facility but Jamla village, Chapariya and NG circle has none special building facilities. Fishermen and fish seller are set temporary roofs, plastic bags and gunny bag sheets to cover fish for protection.

\section{Equipment used by seller's in market}

Fish sellers mainly used knives for cutting the fish with scrappers to remove scales and wooden platform for cutting and filleting. None of the sellers in markets of 
Himmatnagar town found using refrigerator or cold chamber at market place.

\section{Cold chain in Himmatnagar fish market}

Being highly perishable commodity, cold chain forms integral part of fish marketing (Markad et.al 2019). None of the Himmatnagar fish market sellers have an appropriate cold storage and freezing facilities. Himmatnagar town fish market mostly sellers dependent on ice. Fishermen and sellers used crates with fishes mixed with ice. The fishers use ice as per their instinct and experience for maintaining cold chain for fish storage, transport and marketing (Markad et. al 2019).

\section{Species composition}

Fishermen and sellers in all market of Himmatnagar mostly sold freshwater fishers available and caught in guhai dam, small reservoirs and rivers. Mostly available species sold are catla, rohu, mrigal, garass carp, comman carp, magur and pangasius etc.

The finfish and shellfish species sold in the fish markets of sabarkantha district were major carps (Catla, Catla catla; Rohu, Labeo rohita; Mrigal, Cirrhinus mrigala) exotic carps (Common carp, Cyprinus carpio; grass carp, Ctenopharyngodon idella), air breathing fishes (Magur, Clarias batrachus ), shrimps (P. monodone, $P$. stylifera) cat fishes (Pangasius pangasius, Sperata seenhhala).

Indian major carps are the dominate species in fish market followed by exotic carps. During this study Mehtapura 1 and 2 fish market carps were found to be major species. Carps species including catla, rahu, grass carp, common carp, mrigal and other carps were sold in huge quantities in market. Pangasius (Pangasius pangasius) are also major dominate species in all markets.

\section{Price structure of different species}

The Price of species vary considerable depending upon the availability, freshness, and condition of the specimen being sold. Alam et al., (2010) also reported influence of market structure, species quality, size and weight in price of fish. Generally larger fishes get more price compares to smaller ones. We also found that larger fishes fetched better price that smaller during study of Himmatnagar fish market. Himmatnagar fish market depends on different species, size of fishes, and freshness condition to sell in market.

\section{Hygiene status}

The hygiene condition at Fish market of Himmatnagar town under study was found to be very poor condition. Fishes were sold along roadside in NC circle and Mehtapura market 1. The fishes were displayed on polythene sheets, gunny bags and open flour. Cutting knives and platform were not found stored in proper condition and many times seen lying on open grounds full of dirt, mud and dust. The cut fishes were not properly washed before handing over to buyers (Markad et al., 2019).

\section{Women involvement}

Women are involved in many fisheries activities such as aquaculture, fishing, and capture. Mostly female fishermen are observed selling fish and shrimps in all the market of Himmatnagar town. The present study illustrates how women are engaged in selling the fish in Himmatnagar fish market. Women are under the study signifying their major part of market.

\section{Marketing system and Traders involved}

The marketing system of fish market in Himmatnagar was found to be simple one. 
Fishermen families bring their fish catches and sell in market. Mostly fishes caught in morning time and were brought to the market by evening time. Most of the fisherman tries to sell their whole catches on the same day due to unavailability of proper cold storage facilities (Markad et al., 2019). Role of whole seller are limited in Himmatnagar marketing system. Most of the fishermen were found working in individually for fishing as well as selling.

Table.1 List of Retail selling fish markets in Himmatnagar

\begin{tabular}{|c|c|c|}
\hline S. No & Name of place & Day of market \\
\hline $\mathbf{1}$ & Jamla village & Daily \\
\hline $\mathbf{2}$ & Mehtapura market 1 & Daily \\
\hline $\mathbf{3}$ & Mehtapura market 2 & Daily \\
\hline $\mathbf{4}$ & Chapariya & Monday to Saturday \\
\hline $\mathbf{5}$ & NG circle & Monday to Saturday \\
\hline
\end{tabular}

(Source - Field survey 2019)

Table.2 Average Selling Price $(\mathrm{kg})$ and Demand of Fish in Himmatnagar market

\begin{tabular}{|l|l|l|l|l|l|}
\hline S.No & Local Name & \multicolumn{1}{|c|}{ Scientific Name } & $\begin{array}{c}\text { Size of } \\
\text { fish }\end{array}$ & $\begin{array}{c}\text { Price } \\
\mathbf{( K g )}\end{array}$ & \multicolumn{1}{|c|}{ Demand } \\
\hline $\mathbf{0 1}$ & Catla & Catla catla & Large & $150-200$ & High \\
\hline $\mathbf{0 2}$ & Rav & Labeo rohita & Large & $160-200$ & High \\
\hline $\mathbf{0 3}$ & Mrigal & Cirrhinus mrigala & Medium & $160-180$ & Medium \\
\hline $\mathbf{0 4}$ & Nani Rav & Cyprinus carpio & Small & $100-120$ & Medium \\
\hline $\mathbf{0 5}$ & Ek-katali & Pangasius pangasius & Large & $200-280$ & High \\
\hline $\mathbf{0 6}$ & Kata Vinani & Sperata seenhhala & Large & $180-200$ & High \\
\hline $\mathbf{0 7}$ & Magur & Clarias batrachus & Large & $120-160$ & Medium \\
\hline $\mathbf{0 8}$ & Paplet & Pampus argenteus & Small & $200-220$ & High \\
\hline $\mathbf{0 9}$ & Machi & Ctenopharyngodon idella & Large & $180-200$ & Low \\
\hline $\mathbf{1 0}$ & Zinga & Parapenaeopsis stylifera & Medium & $200-240$ & High \\
\hline $\mathbf{1 1}$ & Zinga & Penaeus monodon & Medium & $210-250$ & High \\
\hline $\mathbf{1 2}$ & Hilsa & Sardinella longiceps & Medium & $180-200$ & Medium \\
\hline
\end{tabular}

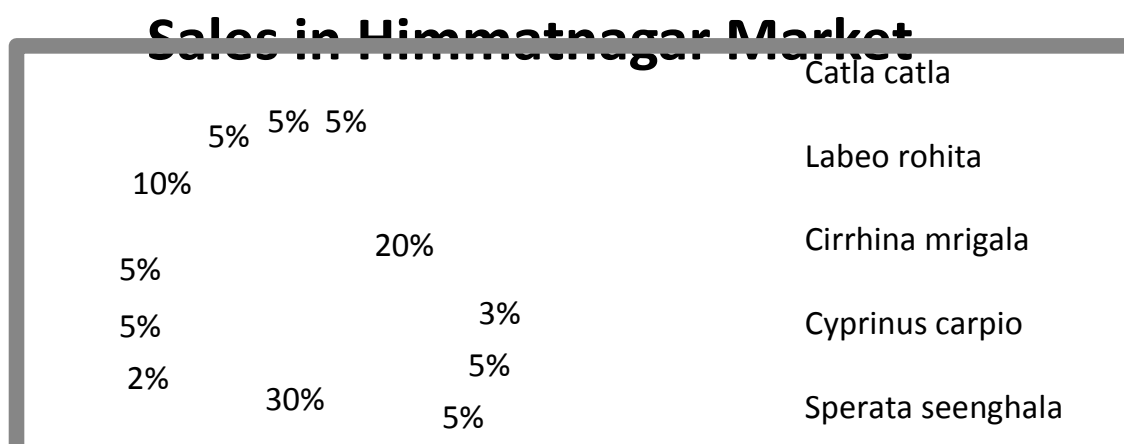




\section{Specific suggestions for market}

Establishment of more ice-plants, coldstorage and preservation facilities

Establishment of modern wholesaling facilities

Introduction of mechanical weighing equipment

Improvement of existing fish market structure

Improvement of sanitation, hygienic condition, drainage, washing facilities and sufficient auction places

An independent act or ordinance for fish landing and marketing

In conclusion, condition of Himmatnagar fish market is poor facilities. Market need to have some development of fish market of the Himmatnagar. Local government may take to develop some basic facilities and infrastructure in fish market. Fisherman should be aware and trained in hygienic fish handling and fish processing.

\section{References}

Abdurrahman, Haroon Zargar, Mohammad Asif, and Sudipta Ramola. "A Survey on Fish Marketing System in Dehradun, India." Archive of Life Science and Environment 1, no. 2 (2017): 1-6.

Chourey P, Meena D, Varma A and Saxena G (2014) Fish marketing system in bhopal (M.P.). Biological Forum -An International Journal 6(1): 19-21.

Chourey, Pratibha, Durga Meena, Alok Varma, and Geeta Saxena. "Fish
Marketing System in Bhopal (M.P.)." Biological Forum - An International Journal 6, no. 1 (2014): 19-21.

Deshmukh, D. R., and C. S. Jawale. "Study of fish markets in Paithan, Dist. Aurangabad, Maharashtra". Trends in Fisheries Research 3, no. 3 (2014): 5 6.

Engle CR and Quagrainie K (2006) Aquaculture marketing handbook. Blackwell Publishing Professional 2121 State Avenue, Ames, Iowa 50014, USA. pp. 37-56. DOI: 10.1002/9780470277690.

Khileri, R.A., S. R. Lende, Vikas, S.A. Muley, and G.P. Deshmukh. "Status of an extreme dry fish market: A study of dry fish market, on the coastal region of Saurashtra, Gujrat." Ecology, Environment and Conservation 21, no. 2 (January 2015): 1027-32.

Markad, S.S., Gaikwad, J.M., Patil, D.W. and Shinde, V.D., Review of Research.

Ravindranath, K. (2008) In National Workshop on Development of Strategies for Domestic Marketing of Fish and Fishery Products, College of Fisheries Science, Nellore, India, pp. 43-48.

Sathiadhas, R., and R. Narayanakumar. "Price Policy and Fish Marketing System in India." Biology Education, OctoberDecember 1994: 225-241.

Shanthi B., M. Krishnan and A.G. Ponniah. Successful Women Entrepreneurs in Aquaculture: Case Studies from Tamil Nadu, India "Asian Fisheries Science" Special IssueVol.25S (2012):177-185.

\section{How to cite this article:}

Vala, S. R., S. R. Lende, K. Jora, H. Dhimmar, J. Mevada, D. Fofandi and Dhimmar, S. 2020. A Study on Fish Marketing System in Himmatnagar, Sabarkantha, Gujarat. Int.J.Curr.Microbiol.App.Sci. 9(01): 1054-1058. doi: https://doi.org/10.20546/ijcmas.2020.901.118 